\title{
Justyna Ciechanowska
}

Katarzyna Szwed ${ }^{1}$

\section{Finansowanie partii politycznych w Republice Estonii}

Słowa kluczowe: Estonia, partie polityczne, finansowanie, źródła finansowania, Estońska Komisja Nadzoru Finansowania Partii

Keywords: Estonia, political parties, funding, sources of funding, Estonian Party Funding Supervision Committee

\section{Streszczenie}

Finansowanie partii politycznych w Estonii determinuje przede wszystkim przyjęta w $1994 \mathrm{r}$. ustawa o partiach politycznych. Była ona wielokrotnie nowelizowana, a ostatnie znaczące zmiany wprowadzono w $2014 \mathrm{r}$. Zakłada ona zróżnicowanie źródeł finansowania partii politycznych i jako takie dopuszcza dotacje przekazywane bezpośrednio $\mathrm{z}$ budżetu państwa. darowizny od osób prywatnych, składki członkowskie, dochody z aktywów i majątku partii politycznej, a także pożyczki i kredyty. Warto odnotować, że gwarancje zachowania zasad transparentności i jawności finansowania partii politycznych zapewnia działalność niezależnego organu kontroli - Estońskiej Komisji Nadzoru Finansowania Partii.

\section{Summary}

\section{Funding of Political Parties in the Republic of Estonia}

Funding of political parties in Estonia is determined mainly by the Political Parties Act enacted in 1994. It was amended many times and the last meaningful modifications were

1 Autorki są adiunktami w Katedrze Prawa Konstytucyjnego Wydziału Prawa i Administracji Uniwersytetu Rzeszowskiego. E-mail: justyna.mokrzycka@gmail.com, kmszwed@gmail.com. 
introduced in 2014. The act assumes a diversification of the financing sources and allows parties to be financed from allocations from the state budget, donations given by a natural persons, membership fees, transactions with the property of the political parties as well as loans. It is worth mentioning that clarity and transparency principles of political parties' funding are guaranteed by an operation of the independent supervisory body Estonian Party Funding Supervision Committee.

I.

Demokratyzacja w Europie Środkowej i Wschodniej wprowadziła zmianę zasad funkcjonowania systemu politycznego. Przede wszystkim w miejsce kierowniczej roli partii komunistycznej wszedł pluralizm polityczny, który oznacza możność tworzenia się partii politycznych odwołujących się do różnorodnych idei. Obecnie z uwagi na zmiany zachodzące w strukturach społecznych, rozwój środków społecznego przekazu, procesy integracyjne, przekształceniom ulegają partie polityczne funkcjonujące w demokratycznych państwach.

Ewolucja systemu finansowania partii politycznych w Estonii wykazuje podobieństwa z procesami zachodzącymi w państwach Europy Środkowej i Wschodniej. Typowe jest dla nich zwiększenie zależności od finansowania z budżetu państwa w stosunku do składek członkowskich czy darowizn, wzrost kosztów ponoszonych na kampanie wyborcze oraz wprowadzanie instytucji zapewniających kontrolę transparentności finansowania partii politycznych, przy jednoczesnym niskim społecznym poparciu dla instytucji partyjnych.

Republika Estonii może jednak pod wieloma względami stanowić przykład do naśladowania. Państwo to podjęło bowiem skuteczne działania na rzecz uszczelnienia systemu finansowania partii politycznych, wyciągając konstruktywne wnioski z nagłośnionych zjawisk korupcyjnych w tej sferze oraz dostosowując ustawodawstwo w tym zakresie do zaleceń wynikających z rekomendacji GRECO (Group of States against Corruption - Grupa Państw Przeciw Korupcji) - organizacji międzynarodowej zajmującej się analizą finansowania polityki. Dotychczasowe zmiany legislacyjne odnoszące się do finansowania partii politycznych w Estonii przyczyniły się do zróżnicowania źródeł 
dochodów, dały podstawy do jasnych reguł finansowania i powołania niezależnego organu kontroli finansowej partii politycznych.

Estonia posiada zrównoważony system finansowania o silnym komponencie publicznym, który jednocześnie zachęca do zbierania środków od darczyńców indywidualnych oraz znosi darowizny od firm i anonimowych darczyńców. Państwo to podjęło efektywne działania w kierunku naprawy systemu finansowania partii politycznych, zarówno w wymiarze prawnym jak i praktycznym.

Celem niniejszych rozważań jest przedstawienie przede wszystkim zasad finasowania partii politycznych w Republice Estonii. Niniejsze opracowanie będzie próbą podsumowania dotychczasowych doświadczeń oraz propozycją zastosowania nowych rozwiązań.

II.

Republika Estonii należy do wielopartyjnego modelu państw nordyckich ${ }^{2}$, w którym występują cztery rodziny partii tj. socjaldemokratyczne, liberalne, konserwatywne i ludowe. Cechą wyróżniającą jest przede wszystkim brak jednej partii politycznej, która byłaby zdolna do przejęcia władzy w państwie ${ }^{3}$. Pierwsze partie polityczne powstały w Estonii na początku XX w. W listopadzie 1905 r. Jaan Tõnnison założył legalną partię estońską: Estońską Ludową Partię Postępowców (Eesti Rahvameelne Koduerakond) oraz mniejszość niemiecka powołała Partię Konstytucyjną. Obydwa ugrupowania postulowały za przekształceniem Rosji w monarchię konstytucyjną oraz za nadaniem przywilejów Estończykom, które dotyczyły m.in. ochrony języka i dziedzictwa narodowego ${ }^{4}$. Rozwój systemu partyjnego nastąpił po odzyskaniu niepodległości tj. po $1918 \mathrm{r}$. Znalazło to wyraz w pierwszych wolnych, parlamentarnych wyborach przeprowadzonych w 1919 r., kiedy to mandaty zostały

2 Szerzej na temat systemów partyjnych w państwach skandynawskich - A. Kubka, Partie polityczne i systemy partyjne Szwecji, Norwegii i Danii na przełomie XX i XXI wieku, Gdańsk 2009, passim; oraz M. Grzybowski, Systemy konstytucyjne państw skandynawskich, Warszawa 2010, s. 45-57.

3 K. Karbowska, Republika Estońska, [w:] Systemy polityczne państw Unii Europejskiej, T. I, red. K. A. Wojtaszczyk, M. Pobożny, Warszawa 2013, s. 373.

4 J. Lewandowski, Historia Estonii, Wrocław 2002, s. 149-150. 
rozdzielone pomiędzy osiem ugrupowań. Miało to ogromny wpływ na podziały wewnątrz parlamentu. Sytuacja taka powodowała negatywne nastroje społeczne i dużą niechęć obywateli do działalności partyjnej i politycznej. Pluralizm polityczny trwał zaledwie do 1934 r., kiedy to w wyniku zamachu stanu partie polityczne zostały zdelegalizowane. Następnie niemiecka a później radziecka okupacja nie pozwoliły na odrodzenie się estońskich ugrupowań partyjnych ${ }^{5}$. Dopiero reformy Michaiła Gorbaczowa w ZSRR przeprowadzone w drugiej połowie lat osiemdziesiątych XX w. zwane Pieriestrojkg spowodowały rozluźnienie mocarstwowej polityki i przyczyniły się do tworzenia przez Estończyków organizacji wspierających idee narodowe. Odżyły tendencje niepodległościowe, zaczęła organizować się opozycja. Działania te doprowadziły do ogłoszenia w 1991 r. niepodległości Estonii i rozpisania wyborów do parlamentu. Podobnie jak w okresie międzywojennym wiele środowisk zaczęło organizować własną reprezentację polityczną. Powstało bardzo dużo małych partii politycznych, które zasadniczo deklarowały poglądy prawicowe i centroprawicowe. Wpływało to na fragmentaryzację sceny politycznej. Stąd w latach 90. XX w. wśród liderów ugrupowań politycznych powstała idea stworzenia bloków wyborczych, które były charakterystycznym elementem ówczesnego systemu partyjnego. Przekształcenia systemu partyjnego, które nastąpiły po 1992 r. dotyczyły przede wszystkim scalenia sceny politycznej, zmniejszenia liczby partii oraz rezygnacji z systemu blokowego. Idea instytucjonalizacji prawnej partii politycznych w Estonii pojawiła się na początku wprowadzanych przemian demokratycznych ${ }^{6}$.

Tradycyjnie jako podstawę istnienia partii politycznych wskazuje się konstytucję estońską, która stanowi, iż każdemu zapewnia się wolność zrzeszania $s i e^{7}$. Warto podkreślić, że członkostwo w partii politycznej podlega ograniczeniom o charakterze podmiotowym. Prawo to przysługuje jedynie obywatelom estońskim ${ }^{8}$.

5 Ibidem, 176-186.

6 W. Kubiniec, System partyjny Estonii, [w:] Systemy partyjne państw Unii Europejskiej, red. B. Kosowska-Gąstoł, Kraków 2010, s. 98-99.

Konstytucja Estonii, tłum. A. Puu, wstęp L. Garlicki, P. Łossowski, Warszawa 2000.

8 Regulacje ustawowe uściślają, iż członkiem partii może być obywatel Estonii lub obywatel Unii Europejskiej z prawem stałego pobytu w Estonii, który posiada pełną zdolność do czynności prawnych i osiągnął wiek 18 lat. W tym samym czasie można być 
Przesłanki tworzenia i likwidacji partii politycznej ujęto bardzo lapidarnie $^{9} . \mathrm{Z}$ art. 48 ustawy zasadniczej wynika zakaz istnienia partii, których „cel lub działalność jest skierowana na zmianę przemocą ustroju konstytucyjnego Estonii lub w inny sposób wchodzą w sprzeczność z ustawodawstwem karny$\mathrm{m} " 10$. Organem właściwym do zawieszenia lub likwidacji partii w razie stwierdzenia naruszenia prawa, a także do nałożenia odpowiednich sankcji jest sąd ${ }^{11}$.

Definicja legalna określa partię polityczną mianem dobrowolnego stowarzyszenia o charakterze politycznym, zrzeszającego obywateli Estońskich, które jest zarejestrowane w procedurze przewidzianej w ustawie i stawia sobie za cel reprezentowanie interesu politycznego swoich członków i zwolenników oraz sprawowanie władzy państwowej i samorządowej. Za wymóg konieczny do zarejestrowania partii uznaje się członkostwo w niej co najmniej 500 osób $^{12}$. Partia polityczna jest organizacją non - profit, do której odnoszą się przepisy ustawy o stowarzyszeniach non - profit ${ }^{13}$ oraz ustawy o partiach politycznych ${ }^{14}$.

członkiem tylko jednej partii politycznej. Zob. art. 5 ust. 1 ustawy o partiach politycznych [Political Parties Act] z 11 maja 1994 r. (RT I 1994, 40,654).

9 T. Saarts, Persistence and decline of political parties: the case of Estonia, "East European Politics" 2015, Vol. 31, nr 2, s. 208-228.

10 Konstytucja Estonii..., s. 41.

11 Konstytucja nie precyzuje jednakże instancji sądowej, ani nie wskazuje właściwego trybu postępowania. Dopiero art. 3 ust. 4 Ustawy o procedurze sądowej w trybie nadzoru konstytucyjnego [Constitutional Review Court Procedure Act] z 13 marca 2002 r. (RT I 2002, 29, 174) udziela odpowiedzi na te wątpliwości. Za organ właściwym uznaje Sąd Państwowy, który rozstrzyga tą kwestię w trybie nadzoru konstytucyjnego. Jedynie rząd może zwrócić się z wnioskiem o stwierdzenie zaistnienia przesłanek określonych w art. 48 ust. 3 Konstytucji Estonii i orzeczenie likwidacji partii politycznej. Por. J. Põld, B. Aavikaoo, R. Laffranque, The Governmental System of Estonia, [w:] Governmental Systems of Central and Eastern European States, red. N. Chronowski, T. Drinóczi, T. Takács, Warszawa 2011, s. 296.

12 W 2014 r. obniżono o połowę liczbę członków konieczną do zarejestrowania partii politycznej. Stworzyło to podstawę do większego otwarcia estońskiej sceny politycznej. Rozwiązanie to sprzyja powstaniu nowych sił politycznych. Zob. Parliament Paves Way for More Colorful Political Scene, http://news.err.ee/v/281136a4-344b-4bcb-98fa542757bdlebe (30.01.2017).

13 Ustawa o stowarzyszeniach non-profit [Non-profit Associations Act] z 6 czerwca 1996 r. (RT I 1996, 42, 811).

14 Ustawa o partiach politycznych z 11 maja 1994 r. (RT I 1994, 40,654). 
Ta ostatnia zawiera szczegółowe regulacje funkcjonowania partii politycznych, przede wszystkim zasady tworzenia, rejestrowania, członkostwa, rozwiązania i wewnętrznej struktury. Nadto daje podstawy finansowania partii politycznych, określając dozwolone źródła finansowania, sprawozdawczość, sankcje za naruszenie dyscypliny finansowej oraz procedury działania najważniejszego organu odpowiedzialnego za monitorowanie właściwego i zgodnego z prawem finansowania partii politycznych w Estonii - Estońskiej Komisji Nadzoru Finansowania Partii (Erakondade Rahastamise Järelevalve Komisjon). Ustawa o partiach politycznych została przyjęta w $1994 \mathrm{r}$. Od tego czasu była około 30 razy nowelizowana. Ostatni raz w 2014 r.

System finansowania partii w Estonii opiera się na czterech filarach. Pierwszym podstawowym źródłem utrzymania są dotacje przekazywane bezpośrednio z budżetu państwa. Oprócz finansowania ze środków publicznych partie polityczne mogą przyjmować darowizny od osób prywatnych. Trzeci filar to składki członkowskie, a także dochody z aktywów i majątku partii politycznej. Ostatni sposób zakłada możliwość zaciągania pożyczek i kredytów ${ }^{15}$. Zróżnicowanie źródeł finansowania partii politycznych należy uznać za pożądane rozwiązanie. Stanowi ono gwarancję zachowania suwerenności i autonomii partii politycznych. Zasoby finansowe są istotnym czynnikiem wpływającym na ich przetrwanie i rozwój, jak również utrzymanie władzy. Tym samym pozostawienie bez regulacji tej przestrzeni funkcjonowania stronnictw politycznych i brak kontroli organów państwowych musiałby niewątpliwie prowadzić do licznych nadużyć oraz wykorzystania partii jako narzędzia gry politycznej ${ }^{16}$.

\section{III.}

Element finansowania partii ze środków publicznych został wprowadzony w Estonii w 1994 r. ${ }^{17}$ Faktycznie zaczął obowiązywać od 1996 r. Głów-

15 Por. B. Jagusiak, Systemy polityczne krajów nadbaltyckich, Warszawa 2013, s. 107-108.

16 Zob. P. Jakubowski, Teoretyczne i prawne podstawy finansowania partii politycznych w Polsce po 1989 roku, „Consensus - Studenckie Zeszyty Naukowe” 2011, nr 15, s. 43.

17 A. Sikk, From Private Organizations to Democratic Infrastructure: Political Parties and the State in Estonia, [w:] Political Parties and the State in Post-Communist Europe, red. P. Kopecký, Oxon 2008, s. 97 i n. 
ną przesłanką było zmniejszenie zależności od wpływów pochodzących ze strony sektora prywatnego i zewnętrznych grup nacisku. Ważnym argumentem było tu także ograniczanie potencjalnego i realnego zjawiska korupcji politycznej ${ }^{18}$. Początkowo wkład państwa był nader skromny. Toteż zdecydowano się na zachowanie finansowania otrzymywanego od osób fizycznych i prawnych. Stan ten obowiązywał do 2003 r., kiedy to zakazano przyjmowania darowizn od osób prawnych ${ }^{19}$. Równocześnie jednak zwiększono dotację z budżetu państwa z 1,28 mln euro do 3,84 mln euro $^{20}$. Proces ten miał charakter progresywny. I tak, w 2014 r. środki te stanowiły już ponad $80 \%$ dochodu partii politycznych. Rok później całkowita wysokość funduszy przydzielonych partiom sytuowała się na poziomie 5,4 mln euro ${ }^{21}$.

Problem finansowania partii politycznych stał się przedmiotem debaty na forum publicznym w Estonii po ujawnieniu nieprawidłowości w finansowaniu partii politycznych. W 2012 r. doszło do skandalu z udziałem Silvera Meikara, byłego członka Partii Reform oraz Priita Toobala sekretarza generalnego Partii Centrum. Ten pierwszy przyznał się do korzystania z dotacji o niejasnym pochodzeniu, a także wskazał inne osoby z łona rodzimej partii, które miały dopuścić się podobnego procederu, w tym również urzędującego ministra sprawiedliwości - Kristena Michala. Natomiast Priit Toobal został oskarżony o fałszowanie dokumentów, po tym jak zwrócił się do Estońskiej Komisji Nadzoru Finansowania Partii o wprowadzenie zmian do sprawozdania finansowego partii i dodania do niego kwoty 11030 euro pochodzącej z darowizn udzielonych na rzecz partii jesienią 2010 r. W 2014 r. został skazany przez sąd, a rok później złożył kasację do estońskiego Sądu Państwowego. To tylko niektóre z przykładów, które w latach 2012-2014 podważyły

18 Widać tu analogie ze skandynawskim rozumieniem finansowania partii politycznych $z$ budżetu państwa. Pomoc finansowa jest tu postrzegana jako fundament demokratycznego systemu rządów. W pierwszej kolejności stanowi bowiem gwarancję pełnego wykonywania przez nie demokratycznych funkcji. Zob. A. Kubka, op.cit., s. 51.

19 A. Sikk, R. Kangur, Estonia: The Increasing Costs and Weak Oversight of Party Finance, [w:] Public Finance and Post-Communist Party Development, red. J. Ikstens, S. D. Roper, Aldershot 2008, s. 63-76.

20 V. Pettai, Estonia, [w:] Financing Democracy: Funding of Political Parties and Election Campaigns and the Risk of Policy Capture, OECD Publishing, Paris 2016, s. 137.

21 Ibidem. 
zaufanie społeczeństwa do partii politycznych i do przejrzystości mechanizmów ich finansowania.

I być może słuszność ma Michael Pinto-Duschinsky, który stwierdza że skandale są siłą napędową reform ${ }^{22}$. W ich wyniku doszło w Estonii do konsolidacji przedstawicieli partii politycznych, działaczy społecznych oraz środowisk opiniotwórczych i ekspertów. Z inicjatywy prezydenta Toomasa Hendrika Ilvesa uruchomiono portal internetowy - Rahvakogu (Zgromadzenie obywateli). Przez kilka miesięcy jego działania zebrano propozycje obywateli odnoszące się m.in. do finansowania partii politycznych ${ }^{23}$.

Efektem szeroko prowadzonych dyskusji było wprowadzenie istotnych zmian do ustawy o partiach politycznych, poprzez modyfikację sposobu rozdziału środków pochodzących z budżetu państwa na rzecz poszczególnych partii. Dotychczas poparcie powyżej $1 \%$ ważnych głosów w wyborach parlamentarnych gwarantowało uzyskanie prawa do subwencji państwowej na działalność ugrupowania. Dofinansowanie to wynosiło wówczas 10 tys. euro w skali roku. Natomiast przy poparciu kształtującym się na poziome $4 \%-16,5$ tys. euro ${ }^{24}$. Regulacje te faworyzowały duże partie tradycyjnie reprezentowane $\mathrm{w}$ parlamencie.

Nowelizacja podniosła próg wyborczy konieczny do przyznania subwencji państwowych dla partii, które co prawda startowały w wyborach, ale nie wprowadziły swoich przedstawicieli do parlamentu. I tak, partia która uzyskała poparcie minimum $2 \%$ i nie większe niż 3\% wszystkich oddanych ważnie głosów ma prawo do co rocznego wsparcia z budżetu państwa w kwocie 30 tys. euro. Wynik wyborczy kształtujący się odpowiednio w przedziale 3\% i nieprzekraczający 4\% oznacza dotację wynoszącą 60 tys. euro w skali roku. Natomiast rezultat w wyborach, który sytuuje się pomiędzy przynajmniej 4 procentowym i nie większym niż 5 procentowym poparciem, upoważnia do otrzymania 100000 euro rocznie. Partie, które przekroczyły 5\% próg wy-

22 M. Pinto-Duschinsky, Rola pieniędzy politycznych, [w:] Finansowanie polityki. Wybory, pieniadze, partie polityczne, red. M. Walecki, Warszawa 2000, s. 16.

${ }^{23}$ Szerzej pisze o tym K. Popławski, Estoński sposób na skandal, http://www.eesti.pl/ estonski-sposob-na-skandal-12378.html (10.06.2017) oraz raport Komisji Europejskiej: European Commission: EU Anti-Corruption Report: Annex 6, Estonia, 2014, s. 5 i n.

24 Por. A. Dragan, D. M. Korzeniowska, J. Tracz-Dral, Finansowanie partii politycznych w wybranych krajach europejskich, Biuro Analiz i Dokumentacji. Zespół Analiz i Opracowań Tematycznych, Warszawa 2011, s. 14. 
borczy i uzyskały miejsce w parlamencie, otrzymują nadal dotację z budżetu państwa w wysokości proporcjonalnej do liczby deputowanych zasiadających w parlamencie ${ }^{25}$. Warte podkreślenia jest to, iż środki przekazywane są z budżetu na podstawie liczby mandatów rozdzielonych poszczególnym partiom w oparciu o metodę d'Hondta, a nie według ogólnej liczby głosów ${ }^{26}$.

$\mathrm{W}$ razie połączenia się partii politycznych przyznane subwencje przysługują nowej partii w wysokości równej sumie subwencji ustalonych dla łączących się partii. Z kolei dotacja z budżetu państwa przysługująca koalicji partii politycznych dzielona jest na rzecz partii wchodzących w jej skład w proporcjach określonych w umowie podziału tychże partii. Prawo do pobierania subwencji ustaje po wykreśleniu wpisu partii z ewidencji, jednak nie później niż w ciągu dwóch miesięcy od podjęcia decyzji o rozwiązaniu partii ${ }^{27}$.

W świetle postanowień ustawy partia polityczna nie może prowadzić działalności gospodarczej ani być akcjonariuszem w spółce posiadającej osobowość prawną. Dopuszcza się natomiast pozyskiwanie dochodów z obrotu obligacjami ${ }^{28}$.

Wzmocnienie roli państwa w finansowaniu partii politycznych rodzi pytanie o ewentualne skutki w postaci chociażby osłabienia powiązań partii politycznych ze społeczeństwem obywatelskim, przy jednoczesnym zacieśnianiu więzi z aparatem państwowym i jego administracją ${ }^{29}$. Może to grozić wyobcowaniem ugrupowań politycznych w społeczeństwie, które-

25 B. Jagusiak, op.cit., s. 108.

26 Ü. Madise, Relationships of the State and Political Parties in Estonia, „Juridica International Law. Law Review. University of Tartu" 2007, XIII, s. 105; M. Kowalska, M. Michalczuk, W. Szefke, System polityczny Estonii, [w:] Systemy polityczne państw Europy Środkowej i Wschodniej, red. W. Sokół, M. Żmigrodzki, Lublin 2005, s. 302.

$27 \$ 12$ ust. 3 ustawy o partiach politycznych, op.cit.

28 Ibidem, $\$ 12^{6}$.

29 Zawłaszczanie sfery polityki przez państwo jest powszechne, zwłaszcza przy wszechobecnej atomizacji i indywidualizacji współczesnych społeczeństw. Bierność i apatia obywateli znajduje wyraz w ich nikłej partycypacji wyborczej, co jest bezpośrednio związane ze słabnącym zaufaniem wobec partii politycznych. Rodzi to obojętność na życie publiczne, a tym samym osłabia społeczną kontrolę nad działalnością partii politycznych. W efekcie czego poszczególne ugrupowania nie zabiegają o współdziałanie elektoratu. O zagrożeniu tym zjawiskiem interesująco pisze J. Macała, Partie polityczne w świecie postpolityki, [w:] Partie polityczne w początkach XXI wieku. Problemy rozwoju, organizacji i funkcjonowania, red. M. Wincławska, Toruń 2013, s. 42-43. 
mu powinny służyć oraz prowadzić do powstania politycznych karteli. W efekcie możliwe jest osłabianie obywatelskiego zaufania do partii politycznych i pojawienie się zniechęcenia wobec struktur władzy. Z pewnością nie sprzyja to stabilności rządów i nie wpływa korzystnie na całokształt funkcjonowania państwa.

IV.

Artur Ławniczak zauważył trafnie, że datki stanowią najbardziej dobrowolną formę popierania stronnictw politycznych ${ }^{30}$. Estońska ustawa o partiach politycznych definiuje dokładnie pojęcie darowizny jako „korzyść finansową podlegającą opodatkowaniu, w tym również usługę, wyłączając nieodpłatną pracę, udzieloną przez osobę fizyczną, która jest obywatelem Estonii lub posiada prawo stałego pobytu lub status długoletniego mieszkańca Estonii, z własnych zasobów na rzecz partii politycznej lub jej członka celem wparcia działań partii politycznej" ${ }^{31}$. Tym samym ex definitione wykluczone jest udzielanie wsparcia finansowego w tej postaci przez obcokrajowców, którzy nie posiadają stałej rezydentury na terenie Estonii albo przynajmniej nie mieszkają na terenie państwa przez dłuższy czas. Partia sama określa procedurę przyjmowania datków i informuje o niej na swojej stronie internetowej. Jest zobowiązana do ujawnienia danych darczyńcy - imienia i nazwiska, numeru identyfikacyjnego (lub daty urodzenia w przypadku ujęcia w raporcie publikowanym na stronie internetowej) oraz terminu i wartości otrzymanej darowizny.

Niedozwolone są datki od osób prawnych, anonimowe oraz ukryte. Obowiązuje także bezwzględny zakaz przyjmowania przez partię darowizny (korzystania z dóbr, usług, praw własności) na specjalnych warunkach, niedostępnych dla innych osób, zwalnianie z wiążących obowiązków i zobowiązań oraz odstąpienia od roszczeń w stosunku do partii politycznej. Ustawa explicite sprzeciwia się praktyce spłacania wydatków partii politycznej przez osoby trzecie lub czynienie ustępstw na rzecz partii politycznej, chyba że takie działania są dostępne również dla innych osób w normal-

\footnotetext{
30 A. Ławniczak, Finansowanie partii politycznych, Warszawa 2001, s. 111.

$31 \$ 12^{3}$ (1) ustawy o partiach politycznych, op.cit.
} 
nych warunkach obrotu gospodarczego. Partia jest zobowiązana do zwrotu darczyńcy niedozwolonej darowizny, a jeśli nie jest to możliwe - przekazać ją skarbowi państwa.

Wsparcie udzielane na rzecz partii nie przybiera jedynie formy pieniężnej. Wartości niepieniężne podlegają wycenie przez rzeczoznawcę lub przyjmuje się cenę rynkową. W przypadku zaniżenia ich wartości, różnicę pomiędzy realną wartością a podaną, uznaje się za darowiznę ukrytą. Co roku przy okazji składania przez partię polityczną sprawozdania finansowego audytor ocenia jeszcze raz zasadność i wysokość przeprowadzonej wyceny darowizn o charakterze niepieniężnym.

Tradycyjnie dofinansowanie ze źródeł prywatnych nie podlegało ograniczeniom. Jednak i to uległo zmianie wraz z ostatnią nowelizacją do estońskiej ustawy o partiach politycznych w 2014 r. Limit wysokości datków od jednej osoby fizycznej wynosi obecnie 1200 euro w danym roku finansowym. Na przestrzeni ostatnich lat finansowanie ze źródeł prywatnych uległo drastycznej redukcji z $90 \%$ do $18 \%{ }^{32}$.

W poczet najprostszych i pierwotnych form zdobywania funduszy na działalność partii politycznej należy zaliczyć składki członkowskie. Tego rodzaju finansowanie mieści się bowiem w sferze tradycyjnego postępowania politycznego i nie wymaga szczególnych umocowań prawnych ${ }^{33}$. W tym kontekście należy zauważyć, że jeszcze do niedawna Estonia mogła poszczycić się niezwykłą dynamiką wzrostu liczby członków skupionych w partiach politycznych. Na przestrzeni 15 lat, to znaczy w latach 1997 - 2013, zanotowano wzrost przynależności do stronnictw politycznych o 470\%. Wskaźniki te były jednymi z najwyższych w Europie. Proces ten został zahamowany w latach 2012 - 2014 w związku z wybuchem skandali z udziałem prominentnych polityków. Dwie największe partie polityczne - Estońska Partia Centrum (Eesti Keskerakond) i Estońska Partia Reform (Eesti Reformierakond) - łącznie gromadzą w swoich szeregach ok. 13 tys. obywateli. Przyjmuje się, że w 2014 r. 6,28\% Estończyków należało do partii politycznych. Niemniej wpływy ze składek członkowskich stanowią jedynie 2\% wszystkich źródeł dochodu partii politycznych.

\footnotetext{
32 V. Pettai, op.cit, s. 137.

33 A. Ławniczak, op.cit, s. 47.
} 
V.

Regulacje ustawowe nakładają bezsprzeczny obowiązek sprawozdawczy w stosunku do partii politycznych. Obejmuje on złożenie Estońskiej Komisji Nadzoru Finansowania Partii kwartalnego raportu o uzyskanych dochodach i zaciągniętych kredytach oraz sprawozdania z poniesionych wydatków. Ponadto w przeciągu miesiąca od wyborów parlamentarnych, lokalnych czy do Parlamentu Europejskiego partia lub koalicja (ewentualnie kandydaci niezależni) przedstawia szczegółowy raport finansowy z nakładów poniesionych przez poszczególnych kandydatów startujących z danej listy wyborczej. W sprawozdaniu ujawnia się także źródła finansowania. Każdy kandydat ponosi odpowiedzialność osobistą za jego zgodność z prawem.

Jeszcze do 2011 r. partie polityczne zobligowane były do składania odrębnego raportu o finansowaniu kampanii wyborczych. Sprawozdania te odbiegały znacząco od siebie poziomem skrupulatności. Wynikało to głównie z braku dostatecznie jasnych uregulowań. Ustawa nie definiowała pojęcia „wydatku na kampanię wyborczą”. Te same wydatki można było zaksięgować zarówno jako działania propagatorskie lub wyborcze. Warto zwrócić uwagę na fakt, że w Estonii nie wyszczególnia się specjalnego funduszu wyborczego, co może rodzić pewne trudności i skutkować arbitralnością w klasyfikowaniu nakładów finansowych. Ostatecznie odstąpiono od tej metody sprawozdawczości na rzecz wspomnianych już kwartalnych raportów.

Sprawozdanie z wydatków związanych z prowadzeniem kampanii wyborczej należy złożyć nie później niż miesiąc od dnia wyborów. Sprawozdania sporządza się na określonych formularzach i składa w terminie do dziesiątego dnia miesiąca następującego po upływie kwartału. Wypada tu zwrócić uwagę na typowy dla tego małego państwa wymóg przesyłania sprawozdań $\mathrm{w}$ formie elektronicznej i ich publikowane na oficjalnej stronie internetowej komisji ${ }^{34}$. Rozwiązanie to z pewnością sprzyja przejrzystości i dostępności prezentowanych danych. Za niewątpliwą zaletę należy uznać brak zwłoki $\mathrm{w}$ ich ogłoszeniu oraz możliwość przeglądania i sortowania zamieszczonych

34 Interesująco na temat przebiegu procesów cyfryzacji w Estonii pisze Kazimierz Popławski na stronach internetowych portalu Przegląd Bałtycki. Artykuł Administracja elektroniczna: być jak Estonia: http://przegladbaltycki.pl/3130, administracja-elektroniczna-byc-estonia.html (31.01.2017). 
informacji. Stanowią one także formę kontroli społecznej sprawowanej także za pośrednictwem mediów.

Na płaszczyźnie kontroli finansowania partii politycznej za końcowy akord należy uznać roczne sprawozdanie przesyłane do elektronicznego rejestru przedsiębiorstw (Registrite ja Infosüsteemide Keskus). Jest ono weryfikowane nie tylko pod kątem podatkowym, ale Estońska Komisja Nadzoru Finansowania Partii bada także kondycje finansową partii, szczególną uwagę poświęcając ugrupowaniom o wysokim stopniu zadłużenia. Tego typu podmioty są bowiem bardziej podatne na naciski i wpływy zewnętrzne.

W tym kontekście warto przypomnieć, że partie polityczne mogą zaciągać pożyczki pod zastaw swojego majątku lub za poręczeniem członków partii. Jednak kredytodawcą może być jedynie instytucja kredytowa, a pożyczka jest udzielana na warunkach wolnorynkowych ${ }^{35}$. Przy tym zobowiązanie wynikające z umowy kredytowej nie może przekroczyć jednej czwartej wypłacanej z budżetu państwa subwencji przysługującej partiom politycznym. Limitom tym nie podlegają partia bądź koalicja, których dochód całkowity nie przekroczył 50 tys. euro w poprzednim roku rozliczeniowym.

VI.

Niewątpliwie system finansowania partii politycznych powinien cechować się przejrzystością oraz kontrolą nie tylko pozyskiwania, ale także wydatkowania przyznanych środków, zarówno pochodzących z budżetu państwa jak i źródeł prywatnych.

W sprawozdaniu z wydatków partii politycznych wyróżnia się trzy rodzaje kosztów - administracyjne, zatrudnienia oraz działalności politycznej. W tej ostatniej kategorii ujmuje się koszty wyborcze. Obejmują one nakłady związane z reklamą, public relations, wydarzeniami publicznymi, działalnością wydawniczą oraz inne obciążenia finansowe ponoszone w związku z działalnością polityczną. Estońska ustawa o partiach politycznych nie wprowadza limitów wydatkowania środków pochodzących z budżetu państwa.

Znaczny odsetek wydatków partii politycznych stanowią koszty związane z prowadzeniem kampanii wyborczej. Szacuje się, że 2015 r. partie i kan-

35 A. Dragan, D. M. Korzeniowska, J. Tracz-Dral, op.cit., s. 15. 
dydaci niezależni przeznaczyli na ten cel ok. $6 \mathrm{mln}$ euro. Tylko w pierwszym kwartale $2015 \mathrm{r}$. partie posiadające reprezentację w parlamencie wydały odpowiednio na działalność polityczną - Estońska Partoa Centrum (Eesti Keskerakond) 900091 euro, Estońska Partia Reform (Eesti Reformierakond) 1 237593 euro, Związek na rzecz Ojczyzny i Republiki (Isamaa ja Res Publica Liit) 1015314 euro Partia Socjaldemokratyczna (Sotsiaa Idemokraatlik Erakond) -879588 euro $^{36}$.

Przez wiele lat przedmiotem kontrowersji był deficyt organu odpowiedzialnego za monitorowanie dyscypliny finansowej poszczególnych partii politycznych ${ }^{37}$. W tym względzie udział Państwowej Komisji Wyborczej odpowiedzialnej jedynie za organizację i przebieg wyborów, w tym również głosowania elektronicznego ${ }^{38}$, był niewystarczający. Finansowanie partii politycznych obejmuje nie tylko kwestie związane $\mathrm{z}$ wydatkami na kampanię wyborczą, ale znacznie szerszy katalog spraw. Natomiast specjalnie powołana parlamentarna komisja antykorupcyjna nie dawała gwarancji pełnej niezależności przeglądu finansów partyjnych. W skład tego gremium wchodzili bowiem parlamentarzyści, a nie chociażby pozbawieni wpływów partyjnych, eksperci, sędziowie czy urzędnicy. Toteż de facto partie kontrolowały same siebie lub też silne ugrupowania miały możliwość kontrolowania słabszych. Ostatecznie mogło to grozić brakiem wyciągania konsekwencji wobec przejawów łamania prawa przez poszczególne partie polityczne.

\footnotetext{
36 Dane za: V. Pettai, op.cit., s. 140.

37 Krytycznie o braku niezależnego organu, który posiadałby czytelny mandat do kontroli finansów partii politycznych i przebiegu finansowania kampanii wyborczych, wypowiedziano się w Raporcie Ewaluacyjnym Trzeciej Rundy Oceny w odniesieniu do Estonii, obszar II - „Przejrzystość finansowania partii politycznych”, przygotowanym przez GRECO - Grupę Państw przeciwko Korupcji (4 kwietnia 2008 r.). Raport jest dostępny w języku angielskim pod adresem internetowym: http://www.coe.int/en/web/ greco/evaluations/estonia (29.01.2017).

38 Wprowadzone w Estonii głosowanie elektroniczne ma wymiar unikalny w skali Europy. Kompetentnie piszą na ten temat: J. Rzucidło, Elektroniczny rząd. Aspekty konstytucyjnoprawne, Warszawa 2015, s. 144-156; M. Musiał-Karg, Internetowe głosowanie w E - stonii na przykładzie wyborów w latach 2005-2009, „Przegląd Politologiczny” 2011, nr 3, s. 99-118. Warto zapoznać się także z J. Ciechanowska, K. Szwed, Doświadczenie Estonii związane z głosowaniem elektronicznym, „Studia Prawnoustrojowe” 2016, nr 32,
} s. 211-222. 
W kwietniu 2011 r. w odpowiedzi na istniejące słabości w systemie egzekwowania przepisów powołano do życia niezależny organ kontroli - Estońską Komisję Nadzoru Finansowania Partii (Erakondade Rahastamise Järelevalve Komisjon). Zakres podmiotowy jej działań obejmuje zarówno pojedyncze partie polityczne oraz ich koalicje, jak również niezależnych kandydatów.

Estońska Komisja Nadzoru Finansowania Partii może zlecić przeprowadzenie audytu, analizuje prawdziwość i rzetelność złożonych sprawozdań finansowych, bada skargi na finansowanie partii jak również ma prawo nakładać karę pieniężną (do 15 tys. euro) i domagać się sankcji karnych w przypadku naruszenia przepisów finansowych. Partie polityczne są także zobowiązane do informowania jej o bieżących rachunkach bankowych ${ }^{39}$.

Kompozycja osobowa tego organu została znacznie rozszerzona. Oprócz członków wskazanych przez partie polityczne posiadające reprezentację w parlamencie, jego skład uzupełniają osoby mianowane przez Kanclerza Sprawiedliwości, Państwową Komisję Wyborczą oraz Generalnego Kontrolera. Każdy z nich wyznacza po jednej osobie do tego gremium, a równocześnie wskazuje dla niej ewentualnego zastępcę. Kadencja członków komisji wynosi 5 lat, chyba że decyzją organu powołującego na stanowisko zostanie ona skrócona. Warto również zaznaczyć, że osoby reprezentujące poszczególne partie polityczne w komisji nie mogą być deputowanymi ani ministrami. Dzięki temu nie dochodzi więc do sytuacji, w której są oni delegatami swoich partii, tak jak miało to miejsce dotychczas, lecz działają autonomicznie. Pracę komisji wspierają specjalista do spraw administracyjnych i prawnych. Na pierwszym posiedzeniu komisja wybiera ze swego grona przewodniczącego i zastępcę.

Dotychczasowa działalność komisji daje podstawy by sądzić, że możliwe jest zbudowanie w pełni przejrzystego, skutecznego i rzetelnego systemu sprawozdawczości finansowej partii. Przyjęty obecnie model kontroli finansowania partii politycznych w Estonii jest w większości oceniany pozytywnie przez polityków i obywateli. Niemniej słyszalne są również opinie mówiące

39 O zaletach gromadzenia pieniędzy na rachunkach bankowych dla transparentności zasobów finansowych partii politycznych interesująco pisze: F. Rymarz, Jawność $i$ kontrola finansowania działalności statutowej partii (w praktyce Państwowej Komisji Wyborczej), „Przegląd Sejmowy” 2004, nr 3, s. 43. 
o stronniczości tego organu. Wskazuje się tu bowiem na częstotliwość kontroli jednej z partii - Partii Centrum (Eesti Keskerakond - EK $)^{40}$.

Sankcje za naruszenie przepisów dotyczących reguł finansowania partii politycznych są określone w ustawie o partiach politycznych. Karą grzywny jest zagrożone m.in. przekazanie i przyjęcie zabronionej prawem darowizny, celowe podanie nieprawdziwych lub błędnych danych finansowych, niewywiązanie się z obowiązku złożenia stosownych sprawozdań czy niepoinformowanie komisji o afiliowanych przy partii organizacjach. Czyny te są rozpatrywane przez właściwy sąd.

VII.

Obecny system finansowania partii politycznych w Estonii, choć nie pozbawiony wad, wydaje się spełniać swoje funkcje. Analiza obowiązujących regulacji prawnych pozwala stwierdzić, iż w modelu tym wyraźny jest element finansowania ze środków publicznych. Ustawa o partiach politycznych bardzo szczegółowo normuje kwestie związane z pozyskiwaniem funduszy przez ugrupowania polityczne i sprawozdawczością, natomiast praktycznie pomija strukturę wydatków - wymieniając jedynie dopuszczalne koszty wyborcze. Obowiązująca ustawa z 1994 r. była wielokrotnie nowelizowana, co jednak nie narusza jej spójności.

Warto w tym kontekście docenić przeprowadzenie istotnych reform, po serii skandali związanych z brakiem pełnej transparentności finansowania czołowych estońskich partii. Znaczącej poprawie uległ proces egzekwowania i kontroli działalności finansowej partii. Szczególnie zasługi na tym polu należy przypisać Estońskiej Komisji Nadzoru Finansowania Partii. Ponadto za korzystne zmiany należy uznać wprowadzenie limitów na darowizny prywatne oraz wykluczenie datków ze strony osób prawnych. Natomiast kwestią wartą rozważenia jest wprowadzenie dyscypliny wydatków oraz funduszy celowych.

Ustawodawca estoński podjął skuteczne działania legislacyjne na rzecz dostosowania obowiązujących regulacji prawnych do zaleceń GRECO, a także do walki z wszelkimi przejawami nieprawidłowości w finansowaniu partii politycznych. Brak pełnej finansowej transparentności może o tyle zaskaki-

$40 \quad$ V. Pettai, op.cit., s. 137. 
wać, że Estonia jest powszechnie uznawana za kraj o niewielkim stopniu korupcji w sferze publicznej. W tym niewielkim państwie tego typu zjawiska muszą zatem budzić szczególne kontrowersje. Znamienne jest tu także obywatelskie i aktywne nastawienie społeczeństwa, które angażuje się w zmianę przepisów prawa w tym zakresie. Niewątpliwie Estonia podjęła właściwe działania w kierunku poprawy systemu finansowania partii politycznych, zarówno w wymiarze prawnym jak i praktycznym.

\section{Literatura}

Ciechanowska J., Szwed K., Doświadczenie Estonii związane z głosowaniem elektronicznym, „Studia Prawnoustrojowe” 2016, nr 32.

Dragan A., Korzeniowska D. M., Tracz-Dral J., Finansowanie partii politycznych w wybranych krajach europejskich, Biuro Analiz i Dokumentacji. Zespół Analiz i Opracowań Tematycznych, Warszawa 2011.

Grzybowski M., Systemy konstytucyjne państw skandynawskich, Warszawa 2010.

Jagusiak B., Systemy polityczne krajów nadbałtyckich, Warszawa 2013.

Jakubowski P., Teoretyczne i prawne podstawy finansowania partii politycznych $w$ Polsce po 1989 roku, „Consensus - Studenckie Zeszyty Naukowe” 2011, nr 15.

Karbowska K., Republika Estońska, [w:] Systemy polityczne państw Unii Europejskiej, Tom I, red. K. A. Wojtaszczyk, M. Pobożny, Warszawa 2013.

Konstytucja Estonii, tłum. A. Puu, wstęp L. Garlicki, P. Łossowski, Warszawa 2000.

Kowalska M., Michalczuk M., Szefke W., System polityczny Estonii, [w:] Systemy polityczne państw Europy Środkowej $i$ Wschodniej, red. W. Sokół, M. Żmigrodzki, Lublin 2005.

Kubiniec W., System partyjny Estonii, [w:] Systemy partyjne państw Unii Europejskiej, red. B. Kosowska-Gąstol, Kraków 2010.

Kubka A., Partie polityczne i systemy partyjne Szwecji, Norwegii i Danii na przełomie XX i XXI wieku, Gdańsk 2009.

Lewandowski J., Historia Estonii, Wrocław 2002.

Ławniczak A., Finansowanie partii politycznych, Warszawa 2001.

Macała J., Partie polityczne w świecie postpolityki, [w:] Partie polityczne w poczatkach XXI wieku. Problemy rozwoju, organizacji i funkcjonowania, red. M. Wincławska, Toruń 2013.

Madise Ü., Relationships of the State and Political Parties in Estonia, „Juridica International Law. Law Review. University of Tartu" 2007, XIII.

Musiał-Karg M., Internetowe głosowanie w E - stonii na przykładzie wyborów w latach 2005-2009, „Przegląd Politologiczny” 2011, nr 3. 
Pettai V., Estonia, [w:] Financing Democracy: Funding of Political Parties and Election Campaigns and the Risk of Policy Capture, OECD Publishing, Paris 2016.

Pinto-Duschinsky M., Rola pieniędzy politycznych, [w:] Finansowanie polityki. Wybory, pieniądze, partie polityczne, red. M. Walecki, Warszawa 2000.

Popławski K., Administracja elektroniczna: być jak Estonia, http://przegladbaltycki. $\mathrm{pl} / 3130$,administracja-elektroniczna-byc-estonia.html

Popławski K., Estoński sposób na skandal, http://www.eesti.pl/estonski-sposob-na-skandal-12378.html.

Põld J., Aavikaoo B., Laffranque R., The Governmental System of Estonia, [w:] Governmental Systems of Central and Eastern European States, red. N. Chronowski, T. Drinóczi, T. Takács, Warszawa 2011.

Rzucidło J., Elektroniczny rzad. Aspekty konstytucyjnoprawne, Warszawa 2015.

Rymarz F., Jawność i kontrola finansowania działalności statutowej partii (w praktyce Państwowej Komisji Wyborczej), „Przegląd Sejmowy” 2004, nr 3.

Saarts T., Persistence and decline of political parties: the case of Estonia, "East European Politics" 2015, Vol. 31, nr 2.

Sikk A., From Private Organizations to Democratic Infrastructure: Political Parties and the State in Estonia, [w:] Political Parties and the State in Post-Communist Europe, red. P. Kopecký, Oxon 2008.

Sikk A., Kangur R., Estonia: The Increasing Costs and Weak Oversight of Party Finance, [w:] Public Finance and Post-Communist Party Development, red. J. Ikstens, S. D. Roper, Aldershot 2008. 